\title{
EVALUATION OF PAPAYA GENOTYPES USING AGRONOMIC DESCRIPTORS AND ESTIMATION OF GENETIC PARAMETERS
}

\author{
DESCRITORES AGRONÔMICOS E PARÂMETROS GENÉTICOS NA AVALIAÇÃO \\ DE GENÓTIPOS DE MAMOEIROS
}

\author{
Marcelo de Souza SILVA ${ }^{1}$; Sarita LEONEL ${ }^{2}$; Jackson Mirellys Azevêdo SOUZA ${ }^{1}$; \\ Joyce Helena MODESTO ${ }^{1}$; Rafael Bibiano FERREIRA ${ }^{1}$; Ana Carolina Batista BOLFARINI ${ }^{1}$ \\ 1. Ph.D Student, São Paulo State University (UNESP), School of Agriculture, Botucatu, State of Sao Paulo, Brazil, mace-lo- \\ souza@hotmail.com; 2. Ph.D Professor, São Paulo State University (UNESP), School of Agriculture, Botucatu, State of Sao Paulo, \\ Brazil.
}

\begin{abstract}
In Brazil, the improvement of papaya agribusiness is correlated to the estimation of genetic parameters and evaluation of agronomic descriptors; thus enabling less favourable areas for the development and implementation of papaya crops. Therefore, the current study aimed to evaluate quantitative descriptors and to estimate genetic parameters in genotypes of papaya grown under subtropical climate in the state of São Paulo. The experimental design was randomized in block. The experimental units were grouped into seven blocks of five plants each and three treatments, which consisted of three different varieties: Sunrise Solo, Tainung $\mathrm{n}^{\circ} 1$ and local. The psychochemical properties were analysed for plant height; intersection height of first fruits; stem diameter; male, female and hermaphroditic flower percentage; fruit number per plant; production; yield; normal fruits percentage, carpeloid and pentandric fruits; pulp matter; pulp length; pulp diameter; pulp shape; pulp cavity; pulp thickness; peel performance; pulp performance; seeds performance; seeds number; soluble solids; $\mathrm{pH}$; titratable acidity; ratio; technological index; ascorbic acid and reducing sugars. Furthermore, most agronomic descriptors showed high heritability; besides that, the varieties Sunrise Solo and Tainung $\mathrm{n}^{\circ} 1$ performed the best results in Botucatu.
\end{abstract}

KEYWORDS: Carica papaya L.. Genetic improvement, Variety's performance, Genetic diversity.

\section{INTRODUCTION}

Carica, the genus to which papaya belongs, is monotypic and only includes the species Carica papaya $\mathrm{L}$, whose is the most important species from the family Caricaceae (BADILLO, 2000). In 2015, Brazil produced 1.6 million tons of papaya, i.e. $16.7 \%$ of world production (FAO, 2016). The state of Bahia is the largest national producer, followed by Espirito Santo and Minas Gerais, with production of 718.7, 404.7 and 126.8 thousand tons, respectively; thus, representing $80 \%$ of Brazilian papaya production in 2015 (IBGE, 2016).

In the state of São Paulo, which was once the largest national producer, production drastically decreased due to the papaya mosaic virus (Papaya ringspot virus, PRSV-p), that acquired the migratory character and moved to other regions (MARTELLETO; IDE, 2006). Currently, this fruit is being explored by small-scale producers in the northwest of the state, with production equivalent to only $0.7 \%$ of the national production, i.e. 11.8 thousand tons produced in 2015 (IBGE, 2016). However, Sao Paulo has a great potential for papaya commercialization, therefore, small-scale producers can make a good profit by cultivating them.
Despite the economic situation been favourable for growing papaya, there are some obstacles that make its expansion difficult in the country, such as diseases and small number of varieties available for planting, that meet the demands of domestic and foreign markets.

In Brazil, the papaya cultivars most commonly grown are those of 'Solo' and 'Formosa' groups. Genotypes of the group Solo present fruits for export, because they have red colour and small size (between 300 and $650 \mathrm{~g}$ ), while those of the Formosa group have red-orange pulp and average size of 1000 to $1300 \mathrm{~g}$; Formosa group is mainly composed by commercial hybrids, but also may include some lineages (DIAS et al., 2011). The reduced number of varieties available for planting may lead to greater vulnerability to diseases, pests and edaphoclimatic variations, compromising the crop sustainability, due to the high genetic variability.

It is crucial to know about the intensity of genetic variation among nature and the origin of commercially grown papaya, to help growers selecting appropriate management practices, as well as providing information about papaya breeding 
programmes (OCAMPO et al., 2006; OLIVEIRA et al., 2010; DIAS et al., 2011).

The estimation of genetic parameters (i.e. morpho-agronomic and fruit quality traits) in papaya genotypes, allows choosing suitable methods, e.g. simple breeding methods such as mass selection (FOLTRAN et al., 1993). Also, the selection in the segregating populations may reveal great chances of success, due to the wide genotype variability and high heritability values (SILVA et al., 2008). Despite helping farmers on choosing breeding programmes, it also protects new cultivars through registration, but studies are still scarce.

Additionally, the improvement of papaya agribusiness is correlated to the estimation of genetic parameters and evaluation of agronomic descriptors of papaya varieties and hybrids that are available for cultivation, enabling less favourable areas for the development and implementation of papaya crops. According to the above considerations, the current study aimed to evaluate quantitative descriptors and to estimate genetic parameters in papaya genotypes grown under subtropical climate in the state of São Paulo.

\section{MATERIAL AND METHODS}

The experiment was carried out at the Lageado Farm of the School of Agriculture (FCA/UNESP) in Botucatu. The area has the geographical coordinates of $22^{\circ} 51^{\prime} 55^{\prime \prime} \mathrm{S} 48^{\circ} 26^{\prime} 22^{\prime \prime} \mathrm{W}$ at an altitude of $810 \mathrm{~m}$. The climate type is mesothermic, Cwa, that is, subtropical humid with dry winter and rainfall from November to April, with average annual precipitation of $1433 \mathrm{~mm}$; relative humidity of $71 \%$; and average annual temperature of $19.3^{\circ} \mathrm{C}$ (CUNHA; MARTINS, 2009). Soil was classified as Red Nitosol according to the Brazilian Soil Classification System (EMBRAPA, 2013).

The experiment can be described as randomized block design. The experimental units were grouped into seven blocks of five plants each and three treatments that corresponded to the varieties: Sunrise Solo, Tainung $\mathrm{n}^{\circ} 1$ and local. Planting was carried out in March 2014, at a spacing of 2 x $2 \mathrm{~m}$; cultural methods were used as recommended for the crop, except for sexing.

To this end, 29 quantitative agronomic descriptors related to plants, fruits and seeds were evaluated in three papaya genotypes that included crops and local variety from June 2014 to July 2015. The descriptors are part of the list proposed for the papaya (INTERNATIONAL PLANT GENETIC RESOURCES INSTITUTE, 1988); therefore, plant height (PH); stem diameter (SD); intersection height of the first fruits (IHFF) were determined by using a tape measure at three months after planting and expressed in $\mathrm{cm}$; male flowers percentages (MFP), female flowers percentages (FFP) and hermaphroditic flower percentage (HFP) were determined through plant sex identification at the beginning of flowering; number of fruits per plant (NFP) were counted during harvesting; production (PRO) was determined by weighing the harvested fruits in each plant and expressed in kg.plant ${ }^{-1}$; yield (YIELD) by considering a stand of 2500 plants.ha $^{-1}$ and expressed in t.ha ${ }^{-1}$; normal fruits percentage (NFP); carpeloids fruit percentage (CFP) and pentandric fruit percentage (PFP), in which each harvested fruit was individually analysed to assess the presence or absence of these abnormalities.

Additionally, physical descriptors were measured for fruit matter (FM) with the aid of an analytical balance and expressed in $\mathrm{kg}$; fruit length (FL) and diameter (FD) were measured with tape measure and expressed in $\mathrm{cm}$; fruit shape (FS), through the relationship between papaya fruit length and diameter; internal cavity diameter (ICD) and pulp thickness (PT), measured with digital calliper and expressed in $\mathrm{cm}$; peel performance (PEELP), pulp performance (PULPP) and seed performance (SEEDP), based on the relation between the contents of peel, pulp and seeds by fruit matter and expressed in percentage; seeds number $(\mathrm{SN})$ were counted per fruit.

Physicochemical descriptors estimated soluble solids (SS) were measured by using a refractometer and expressed in ${ }^{\circ}$ Brix; $\mathrm{pH}$ measurements were obtained by a digital $\mathrm{pH}$ meter; titratable acidity (TA), as described in AOAC (2005); ratio, based on the relationship between SS and TA contents; technological index (TI) by considering SS $\mathrm{x}$ PY/100 (CHITARRA; CHITARRA, 2005); ascorbic acid content (AA) was expressed as $\mathrm{mg}$ ascorbic acid in $100 \mathrm{~g}$ of pulp; and reducing sugars (RS), as described by Nelson (1944).

Fruit characteristics were evaluated by considering five fruits randomly harvested in the second ripening stage, when begin to show colour change on the peel, from about $25 \%$ yellow. However, physicochemical analysis was performed when fruits reached stage 5 , in other words, when showed full colour change on the peel, i.e. $100 \%$ yellow (JACOMINO et al., 2002).

The data obtained were subjected to analysis of variance, according to the mathematical model: Yij $=m+t i+b j+e i j$, where: Yij is the value observed for the characteristic in the i-th study, in 
the $\mathrm{j}$-th block; $\mathrm{m}$ is the general average common to all observations; ti is the effect of the $\mathrm{i}$-th treatment on Yij; bj is the effect of the j-th block on Yij; and eij is the experimental error associated with Yij. Then, genetic parameters estimated were phenotypic variance $\left(\sigma^{2} \mathrm{f}\right)$, genotypic $\left(\sigma^{2} \mathrm{~g}\right)$, heritability of the characters evaluated in the broad sense $\left(h^{2}\right)$, coefficients of experimental variation $(\mathrm{CVe})$ and coefficient of genotype variation $(\mathrm{CVg})$, and relation between the coefficient of experimental and genotype variation $(\mathrm{CVg} / \mathrm{CVe})$.

The genotypes averages were compared by the Tukey test, at 5\% probability. All statistical analyses were performed by using the Genes program (CRUZ, 2006).

\section{RESULTS AND DISCUSSION}

There was a significant difference only for the following descriptors: IHFF, MFP, FFP, HFP, NFP, PRO, YIELD, FM, FL, FD, ICD, SEEDP and AA (Table 1). For the variance components, high phenotypic variances $\left(\sigma^{2} f\right)$ were observed for all characteristics (Table 1).

Table 1. Analysis of variance of quantitative descriptors and their respective amplitudes, phenotypic variance $(\sigma 2 \mathrm{f})$, genotypic $(\sigma 2 \mathrm{~g})$, heritability of the characters evaluated in the broad sense (h2), coefficients of experimental variation $(\mathrm{CVe})$ and coefficient of genotype variation $(\mathrm{CVg})$, and relation between the coefficient of experimental and genotype variation $(\mathrm{CVg} / \mathrm{CVe})$ in three genotypes of papaya grown in Botucatu - SP, Brazil, 2016.

\begin{tabular}{|c|c|c|c|c|c|c|c|c|c|c|}
\hline Descriptors $^{1}$ & QMgen. & QMres & Mín. & Máx. & $\sigma_{f}^{2}$ & $\sigma_{g}^{2}$ & $\begin{array}{c}\mathrm{h}^{2} \\
(\%)\end{array}$ & $\begin{array}{l}\mathrm{CVe} \\
(\%)\end{array}$ & $\begin{array}{c}\text { CVg } \\
(\%)\end{array}$ & $\begin{array}{l}\mathrm{CVg} / \\
\mathrm{CVe}\end{array}$ \\
\hline $\mathrm{PH}$ & $61.0^{\mathrm{ns}}$ & 68.1 & 90.0 & 122.8 & 8.7 & - & - & 7.6 & - & - \\
\hline $\mathrm{SD}$ & $36.3^{\text {ns }}$ & 12.0 & 3.4 & 5.1 & 5.2 & 3.5 & 67.0 & 8.0 & 4.3 & 0.5 \\
\hline IHFF & $253.2^{*}$ & 47.5 & 5.7 & 9.1 & 36.2 & 29.4 & 81.3 & 9.0 & 7.0 & 0.8 \\
\hline MFP & $6.636 .9^{* * *}$ & 107.4 & 0 & 80.0 & 948.1 & 107.4 & 98.4 & 58.3 & 171.8 & 2.9 \\
\hline FFP & $1.601 .0^{* * *}$ & 143.5 & 0 & 80.0 & 228.7 & 208.2 & 91.0 & 33.7 & 40.6 & 1.2 \\
\hline HFP & $12.386 .2^{* *}$ & 175.0 & 0 & 100.0 & 1.769 .4 & 1.744 .5 & 98.9 & 28.3 & 89.5 & 3.2 \\
\hline NFP & $764.3^{* *}$ & 46.1 & 2.6 & 39.2 & 109.2 & 102.7 & 94.0 & 47.5 & 69.0 & 1.5 \\
\hline PRO & $303.3^{* *}$ & 21.7 & 2.3 & 27.9 & 43.3 & 40.0 & 92.8 & 45.3 & 61.7 & 1.4 \\
\hline YIELD & $1.895 .9^{* *}$ & 135.7 & 5.7 & 69.8 & 270.8 & 251.5 & 92.8 & 45.3 & 61.7 & 1.4 \\
\hline NFP & $101.5^{\mathrm{ns}}$ & 45.5 & 77.5 & 100.0 & 14.5 & 8.0 & 55.1 & 7.8 & 3.1 & 0.4 \\
\hline CFP & $20.7^{\mathrm{ns}}$ & 36.3 & 0 & 18.2 & 3.0 & - & - & 92.0 & - & - \\
\hline PFP & $25.1^{\mathrm{ns}}$ & 9.9 & 0 & 14.4 & 3.6 & 2.2 & 60.8 & 95.9 & 45.1 & 0.5 \\
\hline FM & $300.9^{* * *}$ & 27.1 & 0.4 & 1.3 & 43.0 & 39.1 & 91.0 & 20.5 & 24.6 & 1.2 \\
\hline FL & $63.0^{*}$ & 9.6 & 13.8 & 27.7 & 9.0 & 7.6 & 84.7 & 17.2 & 15.3 & 0.9 \\
\hline FD & $4.3^{*}$ & 9.4 & 8.0 & 13.5 & 61.5 & 47.9 & 78.0 & 9.4 & 6.7 & 0.7 \\
\hline FS & $0.6^{\text {ns }}$ & 0.5 & 1.4 & 4.2 & 0.1 & 0.02 & 26.9 & 35.9 & 8.2 & 0.2 \\
\hline ICD & $3.3^{*}$ & 7.6 & 4.1 & 8.3 & 47.0 & 36.1 & 76.7 & 15.2 & 10.5 & 0.7 \\
\hline PT & $9.2^{\mathrm{ns}}$ & 4.2 & 1.6 & 2.8 & 1.3 & 0.7 & 54.0 & 9.0 & 3.7 & 0.4 \\
\hline PEELP & $6.0^{\mathrm{ns}}$ & 17.8 & 20.9 & 41.4 & 0.9 & - & - & 17.7 & - & - \\
\hline PULPP & $134.9^{\mathrm{ns}}$ & 43.1 & 53.6 & 90.4 & 19.3 & 13.1 & 68.0 & 9.2 & 5.1 & 0.6 \\
\hline SN & $49.689 .1^{\mathrm{ns}}$ & 12.735 .7 & 43.4 & 501.2 & 7.098 .4 & 5.279 .0 & 74.4 & 52.6 & 33.9 & 0.6 \\
\hline SEEDP & $25.1^{*}$ & 4.7 & 0.8 & 10.4 & 4.2 & 3.4 & 81.4 & 50.9 & 43.5 & 0.9 \\
\hline SS & $1.8^{\mathrm{ns}}$ & 1.7 & 7.8 & 13.1 & 0.3 & 0.001 & 3.5 & 12.8 & 0.9 & 0.1 \\
\hline $\mathrm{pH}$ & $0.02^{\mathrm{ns}}$ & 0.02 & 5.1 & 5.7 & 0.003 & 0001 & 22.0 & 2.4 & 0.5 & 0.2 \\
\hline TA & $0.001^{\mathrm{ns}}$ & 0.001 & 0.1 & 0.2 & 0.0001 & - & - & 31.6 & - & - \\
\hline RATIO & $2.086 .5^{\mathrm{ns}}$ & 957.2 & 65.3 & 192.4 & 2981 & 1613 & 54.1 & 25.9 & 10.6 & 0.4 \\
\hline TI & $1.0^{\mathrm{ns}}$ & 0.7 & 5.7 & 9.1 & 0.1 & 0.5 & 33.1 & 11.2 & 3.0 & 0.3 \\
\hline AA & $0.5^{\mathrm{ns}}$ & 0.2 & 0.9 & 3.6 & 0.1 & 0.03 & 47.6 & 28.8 & 10.4 & 0.4 \\
\hline $\mathrm{RS}$ & $2.278 .5^{*}$ & 524.8 & 76.5 & 155.5 & 325.5 & 250.5 & 77.0 & 19.3 & 13.3 & 0.7 \\
\hline
\end{tabular}

${ }^{1}$ Plant height (PH); stem diameter (SD); intersection height of the first fruits (IHFF); male flowers percentages (MFP), female flowers percentages (FFP) and hermaphroditic flower percentage (HFP); number of fruits per plant (NFP); production (PRO); yield (YIELD); normal fruits percentage (NFP); carpeloids fruit percentage (CFP) and pentandric fruit percentage (PFP); fruit matter (FM); fruit length (FL) and diameter (FD); fruit shape (FS); internal cavity diameter (ICD; pulp thickness (PT); peel performance (PEELP); pulp performance (PULPP) and seed performance (SEEDP); seeds number (SN); soluble solids (SS); pH; titratable acidity (TA); ratio (SS/TA); technological index (TI); ascorbic acid content (AA) and reducing sugars (RS). ${ }^{\text {ns }}$ not significant, *significant at $5 \%$ probability, and **significant at $1 \%$ probability, by the F test; (-) was not possible to estimate. 
The results were like those obtained by Dias et al. (2011), studying different papaya lineages in Cruz das Almas, state of Bahia. The estimative of genetic parameters, which is crucial in plant breeding, allows identifying genetic variability and evaluates the efficiency of breeding strategies to maximize gains; besides that, allow knowing and maintaining the genetic variability of population (CRUZ et al., 2004).

The low heritability values $\left(\mathrm{h}^{2}\right)$ on some characteristics (i.e. FS, SS, pH and TI) have shown that they were not recommended to be used for selecting papaya plants from the genetic improvement point of view, such as mass selection. However, only low heritability values $\left(\mathrm{h}^{2}\right)$ are not sufficient enough to be used as the most suitable agronomic descriptor for selecting individuals, since there may be no real cause-and-effect relationship. Thus, a high or low heritability $\left(\mathrm{h}^{2}\right)$ may be the result of the effect of other variables, without revealing the relative importance of the direct and indirect effects of these factors (CRUZ et al., 2004).

The high values of CVe (>30\%) for MFP, FFP, NFP, PRO, YIELD, CFP, PFP, FS, SN, SEEDP e TA are due to the large amplitude found in the averages of these observations and the presence of dioecious individuals among the studied accessions. Also, it was not possible to estimate the values for PH, CFP, PEELP and TA of genotypic variance $\left(\sigma^{2} \mathrm{~g}\right)$, heritability $\left(\mathrm{h}^{2}\right), \mathrm{CVg}$ and $\mathrm{CVg} / \mathrm{CVe}$, respectively.

$\mathrm{CVg}$ is an important indicator of the relative magnitude of the possible changes that can be obtained by selecting each descriptor; therefore, in the current study, $\mathrm{CVg}$ values ranged from $0.5 \%$ to $171.8 \%$, between $\mathrm{pH}$ and MFP, respectively (Table 1). While its variation has been of 12.31 and $60.54 \%$ for leaflet petiole length and number of fruits per plant (OLIVEIRA et al., 2010), respectively; 5.39\% for stem diameter at 260 days after planting; and $124.21 \%$ for pentandric fruits (SILVA et al., 2007).

The large variations found in $\mathrm{CVg}$ values is possibly due to the variability of genetic materials used in the analyses, which included a local papaya variety with high intra-access variability. Studies in other cultivars show that high genotypes variability reveals a broad potential of these materials in developing new varieties, since the existence of genetic variation guarantees the success of the producers actions and breeding programmes to identify and select superior plants (SIRISENA; SENANAYAKE, 2000; AYCICEK; YILDIRIM, 2006; BIÇER; ŞAKAR, 2008).

The highest genetic coefficient of variation was obtained in MFP, suggesting the possibility of expressive gains in the selection process to decrease the occurrence of this type of flowers among individuals. The highest estimate for heritability parameter $\left(h^{2}\right)$ in the broad sense also occurred in the MFP, reflecting the same favourable situation (Table 1). It is worth mentioning that among the population of plants studied there were dioecious individuals, corresponding to the local papaya variety.

Although they were no statistically significant difference $(\mathrm{p}>0.05)$ for $\mathrm{PH}$ and $\mathrm{SD}$, they are considered important descriptors in the selection of papaya cultivars, mainly in breeding programmes (Table 2); in addition to knowing, producers get to choose best-adapted varieties for their management conditions (ARAÚJO et al., 2006). In relation to $\mathrm{PH}$, it is preferable that papaya trees are medium height (harvesting efficiency) with short internodes (i.e. less space between fruits), consequently, higher yield (MARIN et al., 2006). The SD is correlated with the plants vigour, that is, the higher the $\mathrm{SD}$, the greater the vigour (FERREIRA et al., 2012).

Table 2. Average of agronomic descriptors related to plant; flowers and yield in three genotypes of papaya grown in Botucatu - SP, Brazil, 2016.

\begin{tabular}{llllllrllllll}
\hline \multicolumn{1}{c}{ Genotypes } & \multirow{2}{*}{ PH } & SD & IHFF & MFP & FFP & HFP & NFP & RO & IELD & NFP & FP & PFP \\
\hline S. Solo & 112.7 & 4.5 & $82.1 \mathrm{a}$ & $0.0 \mathrm{~b}$ & $18.3 \mathrm{~b}$ & $81.7 \mathrm{a}$ & $23.4 \mathrm{a}$ & $1.1 \mathrm{a}$ & $28.6 \mathrm{a}$ & 88.0 & .9 & 4.1 \\
Tainung $\mathrm{n}^{\circ} 1$ & 107.7 & 4.4 & $78.5 \mathrm{ab}$ & $0.0 \mathrm{~b}$ & $41.7 \mathrm{a}$ & $58.3 \mathrm{~b}$ & $16.6 \mathrm{a}$ & $5.2 \mathrm{a}$ & $40.5 \mathrm{a}$ & 88.4 & .0 & 4.6 \\
V. Local & 107.4 & 4.5 & $70.3 \mathrm{~b}$ & $53.3 \mathrm{a}$ & $46.7 \mathrm{a}$ & $0.0 \mathrm{c}$ & $2.9 \mathrm{~b}$ & $.2 \mathrm{~b}$ & $8.0 \mathrm{~b}$ & 94.3 & .6 & 1.1 \\
\hline
\end{tabular}

Means followed by the same lower case letters in the columns do not differ significantly by the Tukey test $(\mathrm{p}<0.05)$. *Plant height $(\mathrm{PH})$; stem diameter (SD); intersection height of the first fruits (IHFF); male flowers percentages (MFP), female flowers percentages (FFP) and hermaphroditic flower percentage (HFP); number of fruits per plant (NFP); production (PRO); yield (YIELD); normal fruits percentage (NFP); carpeloids fruit percentage (CFP) and pentandric fruit percentage (PFP).

With regards to IHFF, it was observed that the local variety presented the lowest average $(70.3 \mathrm{~cm})$ compared to the Sunrise Solo variety (Table 2). The low value of IHFF can be interesting, since it is associated with precocity (DIAS et al., 2011), which allows longer harvest period, higher production per plant and exploration of more advanced cycles of papaya. Many authors 
recommend papaya cultivars that exhibit lower IHFF associated with lower PH (ALONSO et al., 2008; OLIVEIRA et al., 2010).

The presence of local variety contributed to increase the occurrence of male flowers, since the local variety is a dioecious plant lineage, that is, do not produce hermaphroditic flowers. This is confirmed by the fact that there were no hermaphroditic flowers within them (Table 2). When FFP and HFP were analysed, it was observed that the Sunrise Solo variety presented the lowest FFP (18.33\%), while HFP performed the highest value $(81.67 \%)$ compared to the other genotypes studied (Table 2).

From a purely commercial perspective, preference is given to plants with hermaphroditic flowers, as they will produce fruits with an elongated, peripheral-elongated or oblong-elongated shape, with an internal cavity smaller than that of papaya produced by female plants; thus, higher market value (DANTAS et al., 2003). Additionally, $\mathrm{F}_{2}$ generation seeds were used for Tainung $\mathrm{n}^{\circ} 1$ hybrid, which justifies the high percentage of female flowers compared to the plants of the Sunrise Solo variety. This process results from gene segregation, which increases in frequency from generation to generation, and is reported by many authors as one of the main causes of productive losses in papaya (MARIN et al., 2006).

Regarding to the NFP, PRO and YIELD, the varieties Sunrise Solo and Tainung $\mathrm{n}^{\circ} 1$ presented the highest averages (Table 2). The NFP averages for Tainung $\mathrm{n}^{\circ} 1$ hybrid and Sunrise Solo variety were 16.6 and 23.4, respectively. Nascimento et al. (2008) evaluated different accessions of papaya from Solo and Formosa groups in Linhares, state of Espirito Santos; and found variation for the number of fruits per plant at 12 months of planting, from
11.9 to 71.5 . The low NFP obtained in local variety (2.9) is mainly due to the large MFP, consequently, fruits were not produced (Table 2).

The genotypes Sunrise Solo and Tainung $\mathrm{n}^{\circ} 1$ presented yield values of 28.6 and $40.5 \mathrm{t} \mathrm{ha}^{-1}$, respectively (Table 2). Marin et al. (2006) obtained average annual yield from 27 to 60, i.e. $72-84$ fruits per plant. Fraife Filho et al. (2001) studied Tainung $\mathrm{n}^{\circ} 1$ hybrid and obtained yields superior to those found in the mentioned work, with annual average of 50-60 tha ${ }^{-1}$. However, it should be noted that this hybrid yield (40.5 t.ha $\left.{ }^{-1}\right)$ under the current study conditions was higher than the national average (40 t.ha $\left.{ }^{-1}\right)$.

Within the three evaluated genotypes, CFP and PFP are below the minimum tolerated rate for papaya in which is up to $10 \%$ of the fruits (DANTAS et al., 2003). Damasceno Júnior et al. (2008) studied 23 lineages and 22 hybrids obtained between Solo and Formosa lineages and observed that lineages from 'Solo' group tended to be more sensitive to carpeloid and pentandric fruits. Almeida et al. (2003) obtained carpeloid values from 0 to $22 \%$ by using Sunrise Solo 72/12 variety; such anomaly was responsible for large production losses during summer.

The highest FM values were obtained in the Tainung $\mathrm{n}^{\circ} 1$ hybrid $(880.63 \mathrm{~g})$ and local variety $(963.85 \mathrm{~g})$ compared to Sunrise Solo variety $(570.43 \mathrm{~g})$, such results are related to the genetic characteristics of these genotypes (Table 3). In the current study, FM indicates economic potential of this fruit in the region, as papayas could easily meet fruit matter standards for both domestic and foreign market, which is $800-1500 \mathrm{~g}$ for Papaya Formosa and 300-650 g for Solo group (DIAS et al., 2011; DANTAS et al., 2015).

Table 3. Average of agronomic descriptors related to physical attributes of fruits of papaya grown in Botucatu SP, Brazil, 2016.

\begin{tabular}{lllllllllll}
\hline \multicolumn{1}{c}{ Genotypes } & FM & FL & FD & FS & ICD & PT & PEELP & PULPP & SN & SEEDP \\
\hline S. Solo & $570.4 \mathrm{~b}$ & $15.0 \mathrm{~b}$ & $9.5 \mathrm{~b}$ & 1.6 & $5.0 \mathrm{~b}$ & 2.3 & 25.1 & 66.7 & $237.7 \mathrm{ab}$ & $6.5 \mathrm{a}$ \\
Tainung n $^{\circ} 1$ & $963.8 \mathrm{a}$ & $21.0 \mathrm{a}$ & $11.0 \mathrm{a}$ & 1.9 & $6.0 \mathrm{ab}$ & 2.4 & 26.7 & 71.4 & $284.8 \mathrm{a}$ & $3.4 \mathrm{ab}$ \\
V. Local & $880.3 \mathrm{a}$ & $18.2 \mathrm{ab}$ & $10.5 \mathrm{ab}$ & 2.2 & $6.3 \mathrm{a}$ & 2.2 & 26.8 & 75.5 & $121.1 \mathrm{~b}$ & $2.4 \mathrm{~b}$ \\
\hline
\end{tabular}

Means followed by the same lower case letters in the columns do not differ significantly by the Tukey test $(\mathrm{p}<0.05)$. *Fruit matter (FM); fruit length (FL) and diameter (FD); fruit shape (FS); internal cavity diameter (ICD; pulp thickness (PT); peel performance (PEELP); pulp performance (PULPP); seeds number (SN) and seed performance (SEEDP).

For FL and FD, Tainung $\mathrm{n}^{\circ} 1$ hybrid only showed a significant difference $(\mathrm{p}<0.05)$ to Sunrise Solo variety (Table 3 ). Silva et al. (2015) evaluated the quality of Formosa papaya within different growing areas and commercialized in General
Warehousing Companies of São Paulo (CEAGESP), found similar averages for FL and FD to the current study, with values of $25.6 \mathrm{~cm}$ and $11.0 \mathrm{~cm}$, respectively. The variation in the fruits physical characteristics can be related to the genetic profile 
of each material, edaphoclimatic conditions, cultural treatments, cultivar, planting season and growing areas (BERILLI et al., 2007).

The lowest average for ICD was obtained in the Sunrise Solo variety $(5.0 \mathrm{~cm})$, which is associated with the fact that all fruits of this genotype were mostly derived from hermaphroditic flowers (Table 3). The lower internal cavity diameter is obtained in hermaphroditic papaya plants, whereas female plants produce fruits whose internal cavity is large compared to pulp thickness. These quality attributes are very important in the acceptance of the fruits by the consumer markets. Moreover, the lower internal cavity of the fruits is directly correlated with higher pulp content, also reporting that the papayas fruits that present lower ICD are generally more suited for trade in distant markets (DIAS et al., 2011).

With regards to $\mathrm{SN}$, Tainung $\mathrm{n}^{\circ} 1$ hybrid only showed significant difference from local variety; whereas the highest values of SEEDP were found in Sunrise Solo variety, also differing only from local variety (Table 3). Souza et al. (2014) evaluated the quality of popular papaya fruits sold in different commercial establishments, observed an average for seed performance of $9.39 \%$, such results were higher than those found in the current study. Silva et al. (2015) also obtained higher values of papaya seeds performance from the Formosa group grown in different areas, with an average of $7.3 \%$.

For agronomic descriptors related to the physicochemical characteristics of the fruit, a significant difference was observed only for AA content, where the average value of the Sunrise Solo (137.8 mg. $100 \mathrm{~g}^{-1}$ ) was higher than local variety (102.0 mg.100 $\mathrm{g}^{-1}$ ) (Table 4). Although a lower average of $\mathrm{AA}$ was found in fruits from the local variety, this result is interesting for papaya breeding programmes, in order to increase the levels of these nutrients in fruits. Reis el al. (2015) studied the characterization of papaya fruits from new hybrids and lineages of Formosa and Solo group, found values for AA between 91.47 and $115.43 \mathrm{mg} .100 \mathrm{~g}$

1 , which were similar to those obtained in the aforementioned study. Already Zaman et al. (2006), obtained an average value for AA in four varieties of red and yellow papaya of $41.8 \mathrm{mg} \cdot 100 \mathrm{~g}^{-1}$, i.e. values were lower than those obtained in the current study.

Table 4. Average of agronomic descriptors related to physicochemical attributes of fruits of papaya grown in Botucatu - SP, Brazil, 2016.

\begin{tabular}{llllllll} 
Genotypes & SS & pH & TA & RATIO & TI & RS & AA \\
\hline S. Solo & 10.5 & 5.5 & 0.08 & 133.3 & 6.9 & 1.5 & $137.8 \mathrm{a}$ \\
Tainung n $^{\circ} 1$ & 10.8 & 5.4 & 0.09 & 124.7 & 7.7 & 2.0 & $116.0 \mathrm{ab}$ \\
V. Local & 9.8 & 5.3 & 0.10 & 100.1 & 7.3 & 1.6 & $102.0 \mathrm{~b}$ \\
\hline
\end{tabular}

Means followed by the same lower case letters in the columns do not differ significantly by the Tukey test $(\mathrm{p}<0.05)$. *Soluble solids (SS); pH; titratable acidity (TA); ratio (SS/TA); technological index (TI); reducing sugars (RS) and ascorbic acid content (AA).

Although, there was no statistically significant difference ( $\mathrm{p}>0.05)$ in the contents of $\mathrm{SS}, \mathrm{pH}$, TA, RATIO, TI and RS; these attributes are directly related to fruit quality, and in some cases, are considered crucial in the commercialization of papaya. Fagundes and Yamanishi (2001), stated that papayas are suitable for consumption when presenting SS higher than $11.5^{\circ}$ Brix. However, the different edaphoclimatic conditions of each growing area, as well as the degree of maturation of the fruits during harvesting, must be taken into account, factors that directly influence on soluble solids content and other quality attributes related to postharvest fruits (CHITARRA; CHITARRA, 2005).

\section{CONCLUSIONS}

There was a high heritability for most of the agronomic descriptors studied; thus, indicating their potential use in genotype discrimination and crop protection; in addition to the yield and fruit quality outcomes obtained from descriptors, make it possible to indicate the cultivation of Sunrise Solo variety and Tainung $\mathrm{n}^{\circ} 1$ hybrid in Botucatu,

\section{ACKNOWLEDGMENT}

The authors would thank to National Council for Scientific and Technological Development (CNPq) (Process $n^{\circ}$ 304455/2017-2) and the Coordination for the Improvement of Higher Education Personnel (CAPES) to scholarship granted for the studies. 
RESUMO: A estimativa de parâmetros genéticos e a avaliação de descritores agronômicos do mamoeiro pode contribuir com o desenvolvimento do agronegócio do mamão no Brasil, permitindo a expansão de novos cultivos em regiões menos favoráveis para sua exploração comercial. Frente ao exposto, objetivou-se com este trabalho avaliar descritores quantitativos e estimar parâmetros genéticos em genótipos de mamoeiro, cultivados em clima subtropical do estado de São Paulo. O delineamento experimental foi em blocos casualizados, com três tratamentos (variedade Sunrise Solo, híbrido Tainung $\mathrm{n}^{\circ} 1$ e variedade local) e sete blocos, utilizando cinco plantas por parcela experimental. Foram mensuradas as seguintes caraterísticas: altura das plantas e da interseção dos primeiros frutos; diâmetro do caule; porcentagens de plantas masculinas, femininas e hermafroditas; número de frutos por planta; produção; produtividade; porcentagem de frutos normais, carpelóides e pentândricos; massa, comprimento, diâmetro, formato, diâmetro da cavidade interna e espessura da polpa dos frutos; rendimento de casca, de polpa e de sementes; número de sementes; sólidos solúveis; pH; acidez titulável; ratio; índice tecnológico; ácido ascórbico e açúcares redutores. Foi possível inferir com o estudo que há alta herdabilidade quanto à maioria dos descritores agronômicos avaliados e que os bons resultados para a variedade Sunrise Solo e o híbrido Tainung $\mathrm{n}^{\circ}$, possibilitam a indicação desses genótipos para cultivo, na região de Botucatu - SP. genética.

PALAVRAS-CHAVE: Carica papaya L.. Melhoramento genético. Desempenho de variedades. Variação

\section{REFERENCES}

ALMEIDA, F. T.; MARINHO, C. S.; SOUZA, E. F.; GRIPPA, S. Expressão sexual do mamoeiro sob diferentes lâminas de irrigação na região norte fluminense. Revista Brasileira de Fruticultura, Jaboticabal, v. 25, n. 3, p. 383-385, 2003.

ALONSO, M.; TORNET, Y.; RAMOS, R.; FARRÉS, E.; CASTRO, J.; RODRÍGUEZ, M. C. Evaluación de tres cultivares de papaya del Grupo Solo basada em caracteres de crecimiento y productividad. Cultivos Tropicales, La Habana, v. 29, n. 2, p. 59-64, 2008.

ARAÚJO, J. G.; ARAÚJO JÚNIOR, M. M.; MENEZES, R. H. N.; MARTINS, M. R.; LEMOS, R. N. S.; CERQUEIRA, M. C. Efeito do recipiente e ambiente de cultivo sobre o desenvolvimento de mudas de mamoeiro cv. sunrise solo. Revista Brasileira de Fruticultura, Jaboticabal, v. 28, n. 3, p. 526-529, 2006.

\section{ASSOCIATION OF OFFICIAL ANALYTICAL CHEMISTRY. Official methods of analysis of the association of official analytical chemistry. 18.ed. Washington, 2005. 1015p.}

AYCICEK, M.; YILDIRIM, T. Path coefficient analysis of yield and yield components in bread wheat (Triticum aestivum L.) genotypes. Pakistan Journal of Botany, v. 38, p. 417 424, 2006.

BERILLI, S. S.; OLIVEIRA, J. G.; MARINHO, A. B.; LYRA, G. B.; DE SOUSA, E. F.; VIANA, A. P.; BERNARDO, S; PEREIRA, M. G. Avaliação da taxa de crescimento de frutos de mamão (Carica papaya L.) em função das épocas do ano e graus-dias acumulados. Revista Brasileira de Fruticultura, Jaboticabal, v. 29, n. 1, p. 11-14, 2007. https://doi.org/10.1590/S0100-29452007000100005

BIÇER, B. T.; ŞAKAR, D. Heritability and path analysis of some economical characteristics in lentil. Journal of Central European Agriculture, v. 9, p. 191-196, 2008.

BADILLO, V. M. Carica L. vs Vasconcella St. Hil. (Caricaceae): con la rehabilitación de este último. Ernstia, Maracay, v. 10, n. 2, p. 74-79, 2000.

CHITARRA, M. I. F.; CHITARRA, A. B. Pós-colheita de frutos e hortaliças: fisiologia e manuseio. Lavras: Esal/Faepe, 1990. 293p.

CRUZ, C. D.; REGAZZI, A. J.; CARNEIRO, P. C. S. Modelos biométricos aplicados ao melhoramento genético. 3.ed. Viçosa: UFV, 2004. 480p. 
CRUZ, C.D. Programa Genes: estatística experimental e matrizes. Viçosa: UFV, 2006. v.1, 285p.

CUNHA, A. R.; MARTINS, D. Classificação climática para os municípios de Botucatu e São Manuel, SP. Irriga, Botucatu, v. 14, n. 1, p. 1-11, 2009.

DAMASCENO JÚNIOR, P. C.; PEREIRA, T. N. S.; SILVA, F. F.; VIANA, A. P.; PEREIRA, M. G. Comportamento floral de híbridos de mamoeiro (Carica papaya L.) avaliados no verão e na primavera. Ceres, Viçosa - MG, v. 55, n. 4, p. 310-316, 2008.

DANTAS, S. A. F.; OLIVEIRA, S. M. A.; MICHEREFF, S. J.; NASCIMENTO, L. C.; GURGEL, L. M. S.; PESSOA, W. R. L. S. Doenças fúngicas pós-colheita em mamões e laranjas comercializados na Central de Abastecimento do Recife. Fitopatologia Brasileira, Brasília, v. 28, p. 528-533, 2003. https://doi.org/10.1590/S0100-41582003000500010

DIAS, N. L. P; OLIVEIRA, E. J.; DANTAS, E. J. Avaliação de genótipos de mamoeiro com uso de descritores agronômicos e estimação de parâmetros genéticos. Pesquisa Agropecuária Brasileira, Brasília, v. 46, n. 11, p. 1471-1479, 2011. https://doi.org/10.1590/S0100-204X2011001100008

EMBRAPA. Centro Nacional de Pesquisa de Solos. Sistema brasileiro de classificação de solos. 3. ed. Rio de Janeiro: Embrapa Solos, 2013. 306p.

FAGUNDES, G. R.; YAMANISHI, O. K. Características físicas e químicas de frutos de mamoeiro do grupo "solo" comercializados em 4 estabelecimentos de Brasília-DF. Revista Brasileira de Fruticultura, Jaboticabal, n. 3, v. 23, p. $541-545,2001$.

FAO - Food and Agriculture Organization. FAOSTAT Database. Disponível em: < http://faostat.fao.org/site/339/default.aspx>. Acesso em: 20 ago. 2016.

FERREIRA, J. P.; SCHMILDT, O.; SCHMILDT, E. R.; PIANTAVINHA, W. C.; CATTANEO, L. F. Correlações entre características morfo-agronômicas de acessos de mamoeiro. Enciclopédia Biosfera, Centro Científico Conhecer - Goiânia, v. 8, n. 14, p. 246-257, 2012.

FOLTRAN, D. E.; GONÇALVES, P. S.; SABINO, J. C.; IGUE, T.; VILELA, R. C. F. Estimativas de parâmetros genéticos e fenotípicos em mamão. Bragantia, v. 52, p. 7ロ15, 1993.

https://doi.org/10.1590/S0006-87051993000100002

FRAIFE FILHO, G. A.; DANTAS, J. L. L.; LEITE, J. B. V.; OLIVEIRA, J. R. P. Avaliação de variedades de mamoeiro no extremo sul da Bahia. Magistra, Cruz das Almas, v. 13, n. 1. p.1, 2001.

INTERNATIONAL PLANT GENETIC RESOURCES INSTITUTE. Descriptor list for papaya. Rome: IPGRI, 1988. 34p.

IBGE - Instituto Brasileiro de Geografia e Estatística. Mamão: área plantada e quantidade produzida. Disponível em: <http://www.ibge.gov.br/lavourapermanente>. Acesso em: 20 ago. 2016.

JACOMINO, A. P.; KLUGE, R. A.; BRACKMAN, A.; CAMARGO; CASTRO, P. R. Amadurecimento e senescência de mamão com 1-metilciclopropeno. Scientia Agricola, Piracicaba, v. 59, n. 2, p. 303-308, 2002. https://doi.org/10.1590/S0103-90162002000200015

MARTELLETO, L. A. P.; IDE, C. D. Heterosis in papaya hybrids from partial diallel of Solo and Formosa parents. Crop Breeding and Applied Biotechnology, Viçosa, MG, v. 6, p. 24ロ 29, 2006.

MARIN, S. L. D.; PEREIRA, M. G.; AMARAL JUNIOR, A. T.; MARTELLETO, L. A. P.; IDE, C. D. Heterosis in papaya hybrids from partial diallel of Solo and Formosa parents. Crop Breeding and Applied Biotechnology, v. 6, n. 18, p. 24ロ29, 2006. https://doi.org/10.12702/1984-7033.v06n01a04 
NASCIMENTO, L. C.; NERY, A. R.; RODRIGUES, L. N. Controle de Coletrotichum gloeoisporioides em mamoeiro, utilizando extratos vegetais, indutores de resistência e fungicida. Acta Scientiarum Agronomy, Maringa-PR, v. 30, n. 3, p. 313-319, 2008.

NELSON, N. A fotometric adaptation os somogyi method for the determination of glucose. Journal of Biology Chemist., v. 153, p. 375-380, 1944.

OCAMPO, J.; D’EECKENBRUGGEB, G. C.; BRUYÉRE, S.; BELLAIRE, L. L.; OLLITRAULT, P. Organization of morphological and genetic diversity of Caribbean and Venezuelan papaya germplasm. Fruits, v. 61 , p. $25 \square 37,2006$. https://doi.org/10.1051/fruits:2006003

OLIVEIRA, E. J.; LIMA, D. S.; LUCENA, R. S.; MOTTA, T. B. N.; DANTAS, J. L. L. Correlações genéticas e análise de trilha para número de frutos comerciais por planta em mamoeiro. Pesquisa Agropecuária Brasileira, v. 45, p. 855 $\square 862$, 2010. https://doi.org/10.1590/S0100-204X2010000800011

SILVA, F. F.; PEREIRA, M. G.; RAMOS, H. C. C.; DAMASCENO JUNIOR, P. C.; PEREIRA, T. N. S.; GABRIEL, A. P. C.; VIANA, A. P.; DAHER, R. F.; FERREGUETTI, G. A. Estimation of genetic parameters related to morpho $\square$ agronomic and fruit quality traits of papaya. Crop Breeding and Applied Biotechnology,

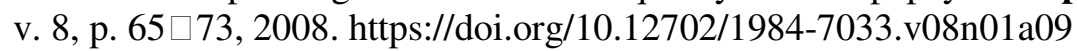

REIS, R. C.; VIANA, E. S.; JESUS, J. L.; LIMA, L. F.; NEVES, T. T.; CONCEIÇÃO, E. A. Compostos bioativos e atividade antioxidante de variedades melhoradas de mamão. Ciência Rural, Santa Maria, v. 45, n. 11, p. 2076-2081, 2015. https://doi.org/10.1590/0103-8478cr20140776

SILVA, F. F.; PEREIRA, M. G.; RAMOS, H. C. C.; DAMASCENO JUNIOR, P. C.; PEREIRA, T. N. S.; IDE, C. D. Genotypic correlations of morpho $\square$ agronomic traits in papaya and implications for genetic breeding. Crop Breeding and Applied Biotechnology, v. 7, p. 345-352, 2007. https://doi.org/10.12702/19847033.v07n04a03

SILVA, M. S.; FERRAZ, R. A.; LEONEL, S. Características físicas e físico-químicas de mamões 'Formosa' provenientes de diferentes regiões de cultivo. Revista Iberoamericana de Tecnología Postcosecha, Hermosillo, v. 16, n. 1, p. 42-48, 2015.

SIRISENA, J. A.; SENANAYAKE, S. G. J. N. Estimation of variability parameters within 'Mysore' banana clones and their implication for crop improvement. Scientia Horticulturae, v. 84, p. 49-66, 2000. https://doi.org/10.1016/S0304-4238(99)00094-1

SOUZA, J. M. A.; ATAÍDE, E. M.; SILVA, M. S. Qualidade pós-colheita e correlação entre características físicas e químicas de frutos de mamoeiro comercializados em Serra Talhada - PE. Magistra, Cruz das Almas, v. 26, n. 4, p. 556-562, 2014.

ZAMAN, W.; BISWAS, S. K.; HELALI, M. O. H.; IBRAHIM, M.; HASSAN, P. Physico $\square$ chemical

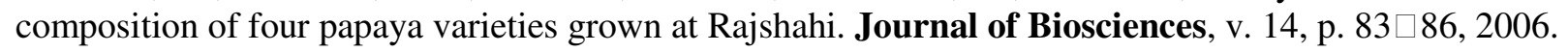

